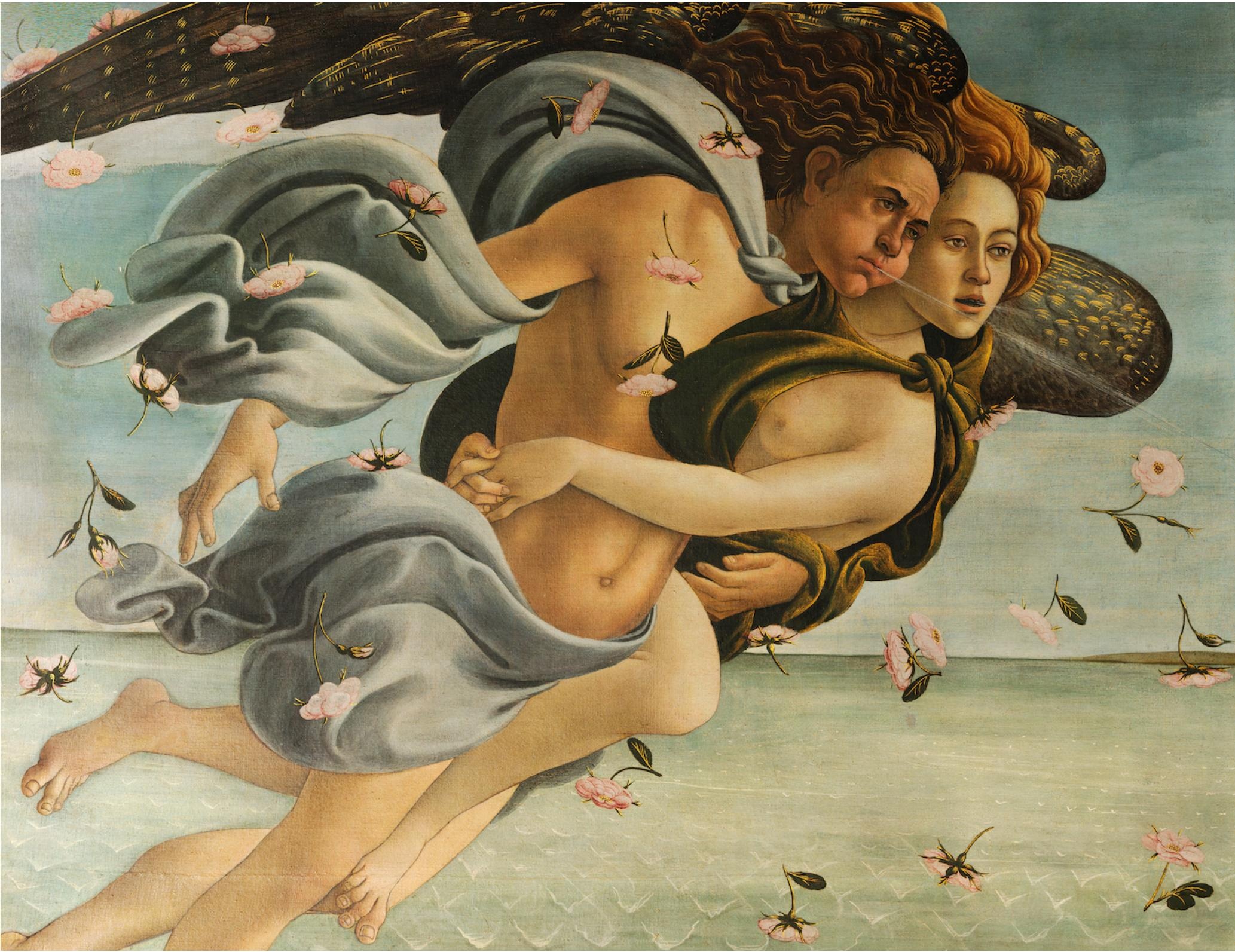

Detail of Sandro Botticelli’s Birth of Venus.

\section{Copy me!}

by Dan C. Baciu, Ph.D.

A foreign boy walks through an Italian city. Brown-haired and brown-eyed, he is not unlike many Italian boys. Based on his facial traits, nobody can find him here; and nobody knows where he goes. An instant later, the world around him changes. A Venus, symbol of beauty, gazes at the boy with her almond eyes and loose, dark blond hair, a tint of red. She is quiet and motionless but desires to be adored. Out of the blue, another girl flies by, hugging the personified Zephyr. She looks at Venus in awe. Then, it starts to rain roses.

This dreamlike world surprises its foreign visitor. Everyone in this world says: "Come closer, look at me!" It is a world very different from the outer world; and it is very different from home; although, seen from within, this world also seems coherent and predictable. A little further, more similar images appear. Another girl is covered in flowers. She presents herself as the personified Spring. She is surrounded by many similar faces; they could be sisters, all radiating the same ideal of beauty. All of these Venuses and
Springs crowd their environment with their gentle silhouettes, too expressive to be true. I should also say that the city in which this flourishing world is located is Florence. The beauties are Botticelli's. They inhabit the Uffizi Galleries. And the boy, that's me. At the Uffizi, I first understood that artworks not only hang on museum walls and are printed in books, but their beauty is reflected in many a visitor's eyes and mind. Botticelli's Venus and Primavera have been reproduced countless times. You can find them on everything from paper to plastic. They are also a likeness of each other. Yet, there exist many more copies of their faces than we think. Imagine yourself as artwork, looking at your visitors. Now find delight in discovering your own tiny copies reflected in the eyes of everyone who looks at you. (You can also enjoy this moment as an actor facing the spectators, or as a regular person, no need to hang on a wall.)

Artworks populate the world between the living and the non-living. They themselves are inert matter, but their visitors bring them to life. Artworks cannot speak by themselves, and yet, they speak through the voices of the people who see them. The main essence of an artwork is the message, "Look at me; copy me in your eyes!" Yet, artworks say more than that. The proof is simple. A foreign 
boy can do the math. Imagine a theoretical world with many artworks in it. Let's assume that initially, all artworks are equally well known, but one of them attracts the public somewhat faster than any other. At first, this advantage might seem negligible, but over time, it plays out all too well. The people who were attracted attract even more people. The volume of their voices grows exponentially, deafening everyone. Eventually, the artwork under consideration wins over the entire world, while all other artworks are forgotten, excluded by competition. Of course, this fiercest of all types of competition is best studied in theory, not in reality. There is one important reason why competitive exclusion is less pronounced in reality. This reason is the second most important message of a real artwork. It says, "Be creative!" As soon as this message makes itself heard, there is no longer one single Venus. Instead, there is the Renaissance. There are ideals, variants, and associations. (To test the potential of creativity in the Renaissance, look at the Zephyr in Botticelli's Venus and compare it with God flying towards Adam in Michelangelo's fresco in the Sistine Chapel. The two figures are variations on the same theme.)

A couple of years after my visit to Florence, I went to Paris and saw Renoir's "Moulin de la Galette," a painting of an open-air restaurant under the trees in Montmartre. How many times did Renoir paint the same faces, the same hats, the same tree branches and sunspots between them, and the same idealized girls he loved? Impressionism reminded me of the Renaissance. Both have their ideals and their creativity. Maybe all styles have that. Back at the Uffizi, I learned about one more message, "Be curious!" As I moved further and further away from Venus, the artworks I saw became increasingly different, only I was becoming increasingly indifferent. My hunger for Renaissance painting was satisfied for the moment. All of these artworks were still Renaissance. They said nothing new. Suddenly, as I moved away from them, I stood in front of Caravaggio's Bacchus, a beautiful melancholy boy somewhat older than me but with a similar name. He was still Renaissance, but he was also something new that pierced through my indifference and nurtured my curiosity. Bacchus hangs in one of the last rooms at the Uffizi. I did not know where it would lead me. Later, I learned that Bacchus was the beginning of the Baroque.

The curiosity that I experienced in front of Caravaggio's Bacchus eventually returned in a new context. In Paris, when I walked through the impressionist collection at the Musée d'Orsay, I suddenly stumbled over one of Vincent van Gogh's self-portraits. Van Gogh was far enough from Impressionism to start something new. Here again, I felt indifference for Impressionism and curiosity towards the new, unknown experience that van Gogh's art provided. Expressionism began with Vincent, but then, my indifference returned and I was curious to learn what Picasso started when he found himself far enough from Expressionism to start what we now know as Cubism.

In Paris, I realized that this pattern of moving apart from the mainstreams served artists to escape from their audience's indifference. This also means that styles are more than a historian's way of sorting out history and placing it into categories. Styles are natural units of cultural evolution. Within the styles, there is creativity, while the relationships between multiple styles are defined by the interplay between indifference and curiosity. This concept can easily be tested. We know that fine art unites many styles. In Italy and France, many people admire the Renaissance, the Baroque, Impressionism, Expressionism, Cubism, and many more styles. These styles compete for audiences. However, the audiences will never settle for any single style. When any style is becoming too popular, indifference and curiosity will change the game. What is too popular becomes commonplace. At the same time new ideas, stimulate our fantasy and attract new interest.

Whenever I look at art, I am forced to recognize that humans have an inborn appreciation for novelty, diversity, and countercultures. This is what makes fine art what it is. With reproduction alone, there is ruthless competition, but art and culture must alleviate this effect. That's why there is both creativity and curiosity. With creativity, the competition between similar artistic expressions is alleviated. Ideals and their variants grow together. Suddenly, we witness the formation of styles and streams. Yet, these styles are still competing with each other, which is only alleviated by curiosity. Mainstreams may tend to outcompete everything else, but then they find themselves facing indifference, whereas alternative cultures may at first seem less successful, but human curiosity supports them. Only with curiosity, multiple styles can coexist on a large scale; and only then, we speak of Art.

The three main messages of artworks-reproduction, creativity, and curiosity - are more than a boy's lessons at the Uffizi. They are the essence of almost all life and evolution. The boy's math of growth rates can be expanded. When I did so, I found myself rediscovering the equations of life: "Copy me!" is the essence of all life because things that are copied spread. Not only are Botticelli's girls similar to each other. Real boys and girls also share common traits. "Be creative!" is the message of almost all evolution. Creativity allows for adaptation. This also applies to information that is encoded not in colors but in genetic base pairs. Genetic mutations keep searching until they turn dinosaurs into birds, land mammals into dolphins, and tree dwellers into modern citizens. "Be curious!" is the message of almost all diversification. Systems that diversify are often more resilient; and through them, evolution can search in multiple directions. Because of diversification, people live in cities and animals in ecosystems.

What's striking is that down to the mathematical details, the consequences of reproduction, creativity, and curiosity are the same for both biological and cultural life. When we see growth, we are faced with the phenomenon of different growth rates and competitive exclusion: The one thing that grows fastest outcompetes all others. This phenomenon is somewhat alleviated when creativity and cooperation come into play. The units of evolutionary selection are now larger than whatever we intuitively interpret as isolated things, objects, or individuals. They are not isolated because they work together and because they are creative. Nevertheless, there still exist units of selection that compete with each other: In art, there are many styles; in biology, there are many species; and in economics, there are bubbles that grow. Eventually, the bubbles grow large enough to burst into nothingness. Then, there is indifference towards whatever is growing too large, and there is recession. Yet, 
indifference towards ubiquitous things opens space for curiosity towards new and rare ones; and this leads to reorientation, and diversification. Here too, the mathematics is the same for both biology and culture.

Galileo, a Florentine contemporary of Caravaggio's, was right in saying that the universe is an open book, and that it is written in the language of mathematics. Galileo was speaking about stars, planets, and comets. I would like to add that the world of art, culture, and ideas is an open book, too. A foreign boy can start reading it; or at least this was my path. My newest insights are found in my most recent research article "Cultural life: Theory and empirical testing" (BioSystems 2020, 197.104208). The article is open access, anyone can read it for free. If you decide to do this, you will get a taste of how I tested my theory against millions of textual records such as news, books, and social media posts. For example, I looked at the history of science. There is ample record of how science diversified and grew since
Galileo and the scientific revolution. Countless people wrote about science. Every record stands testimony for an individual position; every record is like a tiny star out in the universe; every record is a letter in the book of ideas. But Galileo read the book of the universe through his meticulously designed telescopes. In the same line, I am now applying for grants to start a cultural observatory at my new university. My goal is to build a data processing system that collects news and publicly available social media posts from the internet, processes and analyzes what it finds, and helps people see how culture passes through urban space, how it diversifies and grows. Given that the math is now a little more complicated (maybe too difficult for the boy to compute fast enough), the computer can do it; and the computer can also visualize predictions and make them available for everyone online, helping people imagine how cultures (scientific or artistic) might change in their near future.

Dan C. Baciu, Ph.D., is an Assistant Professor of Digital Tools at Delft University of Technology, Netherlands. In his research, Dr. Baciu specializes on big data, computation, and evolutionary dynamics, as applied to the study of how ideas are disseminated and received by entire collectives of people. His theory of cultural life has been most recently published in the journal BioSystems where it instantly became one of the top-ten most frequently downloaded articles https://doi.org/10.1016/j.biosystems.2020.104208

Note: This press article was composed at Convict Lake, California, and in Delft, NL, in summer and fall 2020. 


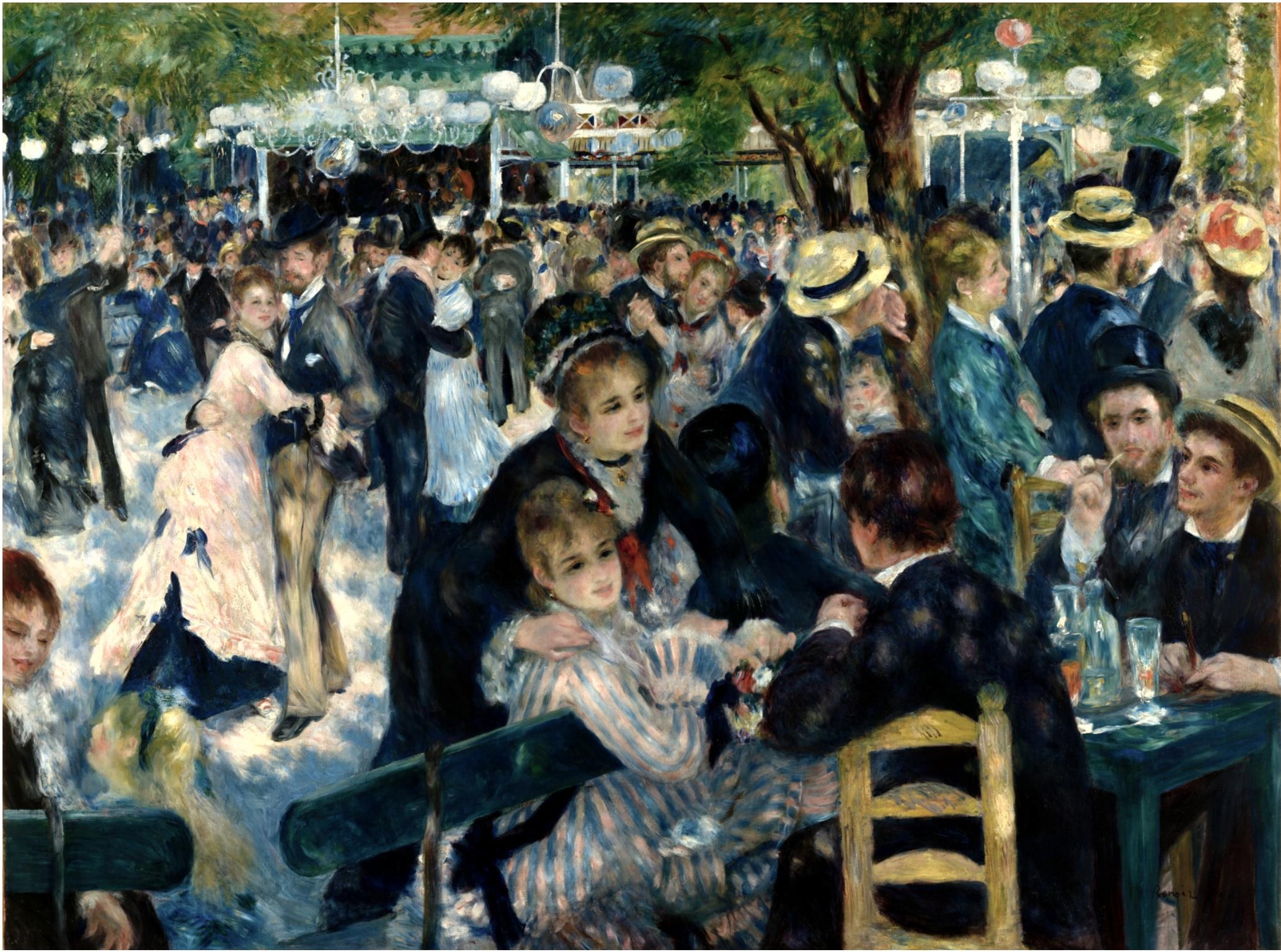

Pierre-Auguste Renoir, Moulin de la Galette.

\section{Copiază-mă!}

de Dan C. Baciu, Ph.D.

Un băiat dintr-o altă țară, un oraș italian, părul castaniu, ochii căprui; trăsăturile feței îl ascund printre băieții localnici. Nimeni n-ar putea spune de unde vine, unde se duce. O clipă mai târziu, lumea se schimbă în jurul lui. O Venus, simbol al frumuseții, se uită la băiat cu ochii ei rotunzi, cu părul ei despletit, blond întunecat. E tăcută și liniștită, dar cere să fie adorată. În zbor, din cerul senin, se avântă o altă fată îmbrățișată de tânărul Zefir. O privește pe Venus cu sufletul plin de iubire. Această lume de vis îl uimește pe noul ei vizitator. Toate îl ademenesc, îl cheamă, "Vino! Vino la noi!" E o lume atât de diferită de cea de afară, de cea deacasă. Totuși, văzută din interior, și această lume pare coerentă, previzibilă. Un pas mai departe, apar mai multe imagini similare. $O$ altă zeiță acoperită în flori, personificarea Primăverii, e înconjurată de chipuri gingașe; ar putea fi surori emanând același ideal de frumusețe. Toate aceste Venere și Primăveri cu siluetele lor elegante se înghesuie una lângă alta, poate prea expresive, prea minunate ca să fie adevărate. Ar trebui, de asemenea, să spun că orașul în care se află această lume înfloritoare este Florența. Frumoasele sunt ale lui Botticelli, iar băiatul care le privește sunt eu. Acolo, la Galeriile Uffizi, am înţeles pentru prima dată, că operele de artă nu numai atârnă pe pereți muzeelor, nu numai populează tipăriturile de artă, ci sunt reflectate, există, în ochii și mintea celor care le privesc. Naşterea Venerei şi Primăvara lui Botticelli au fost reproduse de nenumărate de ori, pe hârtie, pe pânză, pe porțelanuri, sau virtual. Dar orișicare operă de artă are mult mai multe copiicele din ochii tuturor celor care o privesc. Imaginaţi-vă și această situație inversă, situația în care voi sunteți opera de artă privindu-vă vizitatorii. Acuma descoperiţi plăcerea minusculelor imagini din ochii fiecăruia care se uită la voi. (Poate această trăire e asemănătoare cu cea a actorilor aplaudaţi de public, sau a unei persoane oarecare în viaţa ei cotidiană, fără nevoia de a atârna într-o expoziție).

Operele de artă populează lumea obiectelor, dar există si în conștiința oamenilor. Ele sunt materie inertă, dar iau și viață în cei care trăiesc. Operele de artă nu pot vorbi, și totuși vorbesc prin cei care le percep. Esența lor e mesajul, "Vino! Copiază-mă în ochii tăi!" Dar operele de artă ne spun mai mult decât atât. Dovada nu e dificilă; chiar acel băiat ajuns la Florența poate face calculul. Imaginaţi-vă o lume teoretică cu multe opere de artă. La început sunt toate la fel de cunoscute. Dar una dintre ele atrage publicul mai repede şi este discutată mai mult decât celelalte. La început, acest avantaj ar putea părea neglijabil, dar în timp, se va manifesta mult prea bine. Oamenii atrași atrag si mai mulți oameni. Volumul vocilor care vorbesc despre opera de artă cea mai 
atractivă va creste exponențial, asurzindu-ne și acoperind ori ce alt semnal. Peste o vreme, toate celelalte opere de artă vor fi uitate; competiția le exclude. Desigur, această competiție feroce se poate studia cel mai bine in teorie, nu în realitate. Există un motiv important de ce excluderea competitivă este mult mai pronunțată în modelul matematic. Acest motiv este al doilea mesaj al operei de artă: "Fii creativ!" De îndată ce se aude acest mesaj, Venus nu mai este singură, ci dă naștere Renașterii. Idealul se înconjoară cu variantele sale. (Pentru a înțelege potențialul creativității în Renaștere, puteți privi pe Venus si Primavera. Priviți și zborul Zefírului la Botticelli și comparați-l cu zborul lui Dumnezeu către Adam la Michelangelo, pe tavanul Capelei Sixtine.)

Câțiva ani după Florența, am mers la Paris unde am văzut tabloul „Moulin de la Galette” a lui Renoir. Este o grădină de vară a unui restaurant sub copaci în Montmartre. De câte ori n-a pictat Renoir aceleași fețe, aceleași pălării, aceleași ramuri înfrunzite și picăturile de soare dintre ele, aceleași fete idealizate, pe care le iubea. Impresionismul mi-a adus aminte de Renaștere. Amândouă au avut idealurile și creativitatea lor. Poate orice curent artistic se naște din acest joc creator. Dar să ne reîntoarcem la Uffizi. Al treilea mesaj pe care 1-am înteles acolo a fost, "Fii curios!" Cu cât mă îndepărtam de Venus, tablourile deveneau din ce în ce mai diferite - dar eu deveneam din ce în ce mai indiferent. Setea mea de Renaștere se potolise pentru un timp. Toate aceste opere erau "renascentiste"; nu mai spuneau nimic nou. Chiar in acest moment m-am găsit deodată în fața lui Bacchus al lui Caravaggio, un tânăr melancolic, cam de vârsta mea și cu un nume asemănător. Tot renascentist, acest tablou avea și ceva nou, care îmi alungă indiferența și îmi trezi curiozitatea. Pe atunci nu știam unde mă conduce. Mai târziu aveam să aflu că acel Bacchus deschidea drumul spre Baroc.

La Paris, jocul dintre indiferență și curiozitate avea să se dovedească o regulă generală. In colecția impresionistă de la Musée d'Orsay am dat peste un autoportret de van Gogh. Vincent era destul de departe de Impresionism să iniţieze ceva nou, Expresionismul. Apoi Picasso a lansat Cubismul. Ceea ce se anunțase la Florența ca o surpriză unică, se dovedea să fie o surpriză recurentă, o regulă. La Paris, am înțeles că această tendința a artiștilor de a se îndepărta si a se diferenția este necesară pentru a menține interesul publicului. Astfel, se poate spune că stilurile artistice nu sunt doar o modalitate prin care istoricii împart arta în categorii.
Stilurile şi curentele artistice sunt unităţi naturale ale evoluției culturale. In interiorul fiecărui stil guvernează creativitatea. Legătura între mai multe stiluri e definită mai ales de jocul dintre indiferență și curiozitate. Creativitatea unește variantele pe aceeași tema. Datorită curiozității există diferitele stiluri și Arta în sine.

Cele trei mesaje ale operelor de artă — reproducere, creativitate și curiozitate - sunt mai mult decât lecția unui băiat străin in Italia. Ele sunt chiar atributele esențiale ale evoluției. Căutând formula generală a artei, am găsit formula deja cunoscută a materiei vii, a vieții: "Copiază-Mă!" este esența a tot ce trăiește, pentru că ce se copiază se răspândește. Nu numai zeițele lui Botticelli se aseamănă, toți oamenii se aseamănă. Toți avem același genom. "Fii creativ!" Este mesajul general al adaptării. Prin adaptare evoluția caută soluții noi. "Fii Curios!" este mecanismul general al diversificării. Sistemele care se diversifică sunt de regulă mai reziliente; iar prin diversificare, evoluția poate să caute mai multe soluții noi în mai multe direcții.

E frapant că la nivelul modelului matematic, viața biologică și viața culturală se bazează pe aceleași legi: reproducere, creativitate, curiozitate. Când observăm creștere, observăm rate diferite de creștere și excludere competitivă. Acest fenomen este ameliorat în oarecare măsură, atunci când intervin creativitatea și cooperarea. Creativitatea și cooperarea determină arhitectura unităților de selecție naturală. Intuitiv, noi vedem că lumea din jurul nostru constă din obiecte, opere de arta, și indivizi. Prin creativitate și cooperare, unitățile de selecție sunt mai ample decât obiectele, operele, sau indivizii. $\mathrm{Cu}$ toate acestea există unităti de selecție care concurează unele cu altele. În artă sunt stiluri și curente. Unele stiluri au succes mult, cresc și devin curente generale (mainstream-uri), altele rămân curente alternative (countercultures). Tot astfel, în biologie există specii, și dintre specii unele devin abundente, altele rămân rare. În economie există bule care cresc. Apoi, când bulele trec vine recesiunea economică și duce la curiozitate, reorientare și diversificare. Galileo, care trăi la Florența contemporan cu Caravaggio, avea dreptate spunând că universul este o carte deschisă scrisă în limba matematicii. Galileo se referea la stele, planete și comete. Aș vrea să adaug, că și lumea ideilor este o carte deschisă. O carte deschisă din care și băiatul acela dintr-o altă țară a început să citească.

Dan C. Baciu, Ph.D., este Profesor Asistent la TU Delft, Olanda. În cercetările sale, Dr. Baciu este specializat in Big Data, instrumente digitale și dinamica evoluției. Teoria sa a vieții culturale a fost publicată cel mai recent în revista știintifică BioSystems, unde a devenit rapid unul dintre primele zece articole descărcate cel mai frecvent. https://doi.org/10.1016/i.biosystems.2020.104208

Notă: Articolul acesta a fost compus la Convict Lake, California, si Delft, Olanda, in vara si toamna anului 2020. 